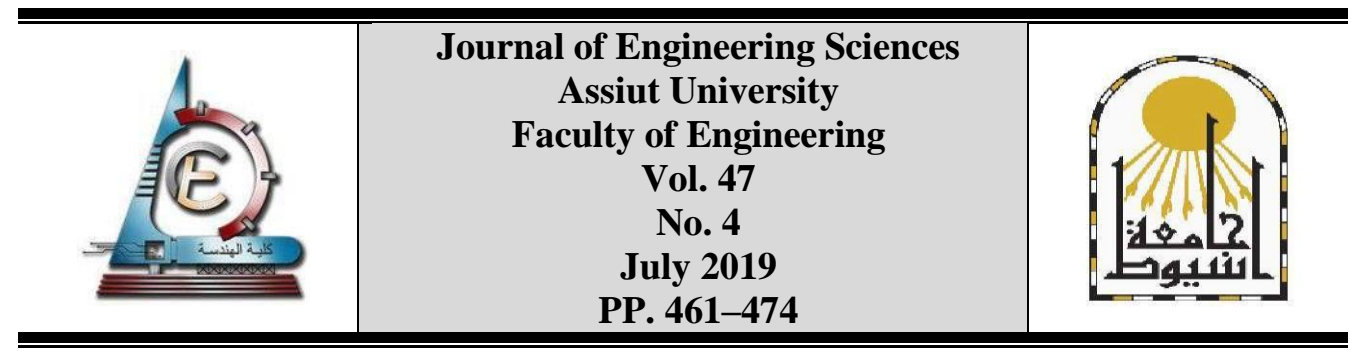

\title{
EXPERIMENTAL STUDY ON BED SCOUR AND ITS PROTECTION BEHIND STANDING WAVE WEIRS CONSIDERING COMBINED FLOW OVER WEIR CRESTAND BOTTOM PIPES
}

\author{
Gamal Abozeid $^{1}$, Waeel E. Mohamed ${ }^{2}$ and Nehal M. E. Osman ${ }^{3}$ \\ ${ }^{1,2}$ Assiut University, Assiut, 71516, Egypt \\ ${ }^{3}$ M.Sc. Researcher
}

Received 24 February 2019; Accepted 31 March 2019

\begin{abstract}
Weirs may be used for measuring of canals discharge, decreasing water slope in canals and distribution of water to canals for irrigation. To empty the water of upstream canal during the maintenance or constructing new water structures and escaping the silt accumulated to downstream, a bottom pipes are installed in weir body near canal bed. Recently, with increasing the demands of water to downstream, a part of flow is passing through the bottom pipes in addition to over weir flow. Most of previous studies concentrate on estimating discharge coefficient of combined flow. However little information are available on scour downstream of this combined flow. So, the objectives of this research are to experimentally investigate the influence of using bottom openings for passing flow with that falling over weir crest on the geometry of scour hole downstream and on the estimation of minimum solid bed length to prevent this scour. The experimental program was performed in a rectangular flume in two categories. Each category was for weir model without working pipes and weir model with two synchronic working bottom pipes with weirs over-flow on scouring. In the first category, solid bed length behind the weir model was chosen to be $600 \mathrm{~mm}$ and the analysis are based on scour hole dimensions and its location behind the model, while the second category is for estimating the minimum solid bed length behind the weir model to prevent scour. Top surface slope of the weir is chosen to be 5:1 and 10:1for both studied categories. The model of the weir is followed by a solid apron following by sand basin. The mean diameter of sand is kept constant at $0.502 \mathrm{~mm}$. The channel bed slope is kept constant at 0.0001, while the discharge and flow depth downstream were varied to cover the required range of Froude number in Egyptian canals. The study revealed that: Using bottom pipes for passing flow with that falls over weir crest helps in reducing scour dimensions behind the weir, as well as reducing the required length of solid bed which considered bed protection. It also found that the required minimum length of solid apron behind the weir to prevent scour is greater than the summation of an arbitrary solid length and the length of scour hole formed downstream of it. Moreover the results showed that the predicted length of scour behind the weir with top surface slope 10:1 is greater than that for 5:1 especially for solid weir with low discharges and low head differences. Empirical formulas in a power function are developed in dimensionless forms for estimating the protected length against scour and the scour dimensions. On the other hand, the comparative analysis with previous studies revealed that the minimum solid bed length behind the weir to prevent scour is greater than the estimated one by using a velocity distribution approach.
\end{abstract}

Keywords: Scour, Standing Wave Weirs, Bottom Pipes, Combined Flow and Minimum floor Length. 


\section{Introduction}

Standing wave weir is the most often type of weirs used in Egyptian, Indian and Pakistanian irrigation channels for measuring the discharge and reducing the head on an existing structure. Ashour, 1974[1] found that the best downstream top surface slope of the standing wave weir is $5: 1$ for small discharges up to a ratio of the upstream water head to the height of weir $=0.5$. Shehata, 2010[2] carried out a series of experimental measurements on the discharge equation for the combination between flow through bottom pipes which is working synchronically with over weir flow. He [2] found passing a partial flow through these pipes reduces the working head over the weir crest. Abozeid, 1989 [3] studied the effects of the geometrical dimension of solid standing wave weir on the scour length behind it utilizing the velocity distributions approach over a horizontal solid bed. He [3] concluded that the top surface slope 10:1 contributes for a rapid adjustment of the velocity distributions to its normal state faster than the other top surface slope. Consequently, the predicted lengths of scour should be shorter in comparison with the studied top surface slopes. El-Attar, 1995[4] performed experiments to study the scour depth below pipe culvert outlets, and showed that the ultimate maximum scour depth below pipe culvert, related to the densimetric Froude number $\left(F_{d}\right)$ and pipe diameter $(D)$ is given by:

$$
d_{s} / D=0.25\left(F_{d}\right)+2.0
$$

Abozeid, 2006[5] found experimentally the minimum solid floor length behind a model of a regulator having three vents with sluice gates to prevent scour is greater than the sum of an arbitrary solid bed length and the length of scour hole formed downstream it. Shenouda, 2008[6] experimentally found the scour behind curved weirs is less than that of straight ones. Ali, 1995[7] studied experimentally the proper location at which the floor sills should be placed behind the hydraulic structures to minimize scour. He found that the proper location of the baffle sill depends on the sill height and the tail water depth and it reduces the length required to prevent scour by 25\%. Negm, 2004[8] experimentally investigated the effect of sill arrangement on maximum scour depth downstream of abruptly enlarged stilling basins. He [8] concluded that the use of sill inside the basin reduces the maximum scour depth downstream of the basin. Hossam, 2012 [9] clarified the effect of bottom pipe locations from the bed on scour downstream clear over fall weir with the combined flow. Sobeih et al. [10] investigated the influence of using openings in weirs on scour hole depth downstream of clear over fall weir. Three cases of opening arrangements were included, no opening, one opening and three openings. Their experiments showed that for most considered values of openings diameter either case of one opening or three openings, the value of $\mathrm{h} / \mathrm{p}=0.25$ gave the smaller values of scour depth, while the value of $h / p=0.5$ gave the higher values of scour depth. Using Artificial Neural Network and the experimental results on scour downstream a model of New Esna barrages, Shenoda, 2014[11] found the minimum length of solid apron of the barrages to prevent scour is greater than the existing one. Guan et al., 2016[12] presented an experimental study of local scour at submerged weirs in sand-bed channels. They [12] studied the effect of sediment size, weir height and tail-water depth on flow regime and scour and proposed a new design method for estimating the maximum scour depths at the submerged weirs. Googheri et al., 2017 [13] used Flow 3D to simulate the temporal changes of scour in combined free flow over weirs and below gates. They [13] compared the numerical results with the experimental ones and found the relative error between them equals $7.36 \%$ and the turbulent energy dissipation was decreased to $38 \%$ at the end of running the model. This decrease led to the creation of scour hole balance. Lu Wang et al., 
Gamal Abozeid et al., Experimental study on bed scour and its protection behind standing wave ........

2018[14] studied experimentally local scour at submerged weirs with different downstream slopes. Their results showed that the upstream scour depth is independent of the downstream weir slope. Also, they [14] found "the downstream weir slope does not affect the downstream scour depth when it is greater than the upstream slope of the downstream scour hole, $\theta$ ". Flume experiments and a Computational Fluid Dynamic (CFD) model were used by Al-Husseini et al., 2019 [15] to study flow properties and scour around four new shapes of submerged weir: inclined sharp crested weirs with $30^{\circ}$ and $120^{\circ}$ slopes, respectively, and two different vertical arch weirs. Their results showed that the inclined sharp crested weir with a $120^{\circ}$ angle reduced the maximum scour depth by more than three times compared to the sharp crested weir and gave minimum scour depth compared with the other models. The objectives of this study are to experimentally investigate the scour formation and its dimensions behind standing wave weir under the conditions of combined flow. The required minimum solid bed length behind the weir to prevent scour is estimated. Empirical formulas in dimensionless forms are developed to estimate scour dimensions and the required minimum solid bed length behind the weir to prevent scour. Verification of the present results with that of previous study approaches is examined.

\section{Experimental works}

The experiments were conducted in a tilting flume located in the hydraulics laboratory of Civil Engineering Department, Assiut University. Water is circulated by a pump to the flume from a return channel leaving from the flume as shown in photo (1). The flow rate can be regulated by a control valve located on a $100 \mathrm{~mm}$. diameter pipeline which discharges directly into the flume. The flow leaving from the flume is directed to a tank found at the end of the flume and then to a return channel. Orifice meter is used for measuring the discharge. The experimental program was performed in two categories. Each category includes two groups. For the first category, solid bed length behind the weir model was chosen according to Bligh, 1912[16] to be $600 \mathrm{~mm}$ to analyze scour dimensions (see Fig. 1). In the second category, to estimate the minimum solid bed length behind the weir to prevent scour, it is assumed to be equal $(600 \mathrm{~mm}+$ the length of scour hole formed in the first category), (see Fig. 2). For both categories, the groups were; weir model without working pipes and weir model with two synchronic working bottom pipes with weirs over flow. Each bottom pipe had $254 \mathrm{~mm}$ diameter $(\mathrm{D} / \mathrm{P}=0.265)$. The top surface slope of the weir was chosen to be 5:1 and 10:1for both studied categories. (see Photo 2). The model was combined of weir body followed by a solid apron following by sand basin. The mean diameter of sand was kept constant at $0.502 \mathrm{~mm}$.

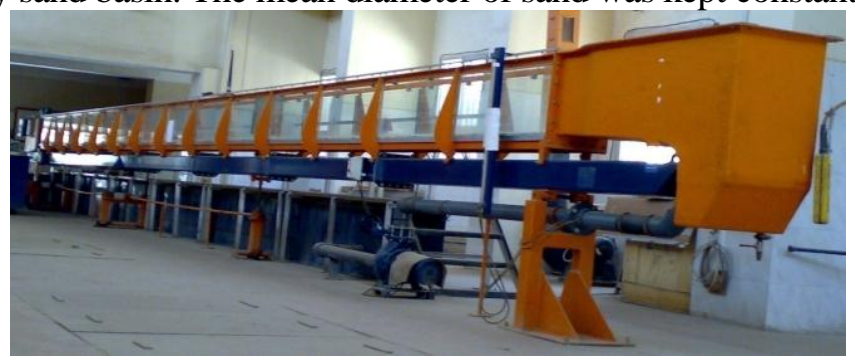

Photo 1. General view of the re-circulating flume.

The channel bed slope was kept constant at 0.0001, while the discharge and flow depth downstream were varied to cover the required range of Froude number (from 0.11 to 0.23 ) as in Egyptian canals [4]. Downstream water depth was controlled by a tail gate located at the end of the flume. Water depths, levels and scour hole dimensions were measured using point gauges. 


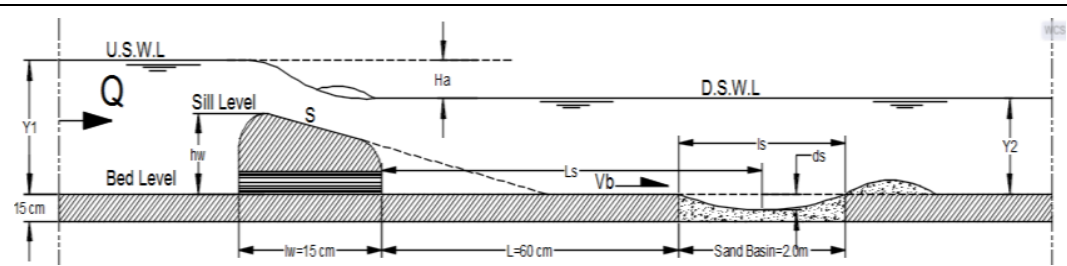

Fig. 1. Definition sketch showing the geometry of scour hole and governing parameters in the first category.

After fixing the weir model on the flume bed at a distance $600 \mathrm{~mm}$ upstream of the sand basin, the experimental procedures for the first category were as follows: 1) Bottom pipes were closed and the desired discharge is flowing (group 1). 2) The channel filled with water. 3) Sand basin was completely leveled. 4) The downstream water depth was adjusted to the desired one $\left(\mathrm{Y}_{2}\right)$ by the tail gate. 5) After 3 hours run time Grade, 1961[17] the upstream water depths $\left(\mathrm{Y}_{1}\right)$, downstream depth $\left(\mathrm{Y}_{2}\right)$, the discharge $(\mathrm{Q})$, the static head over the weir $(\mathrm{H})$, the scour hole length (ls), maximum scour hole depth (ds) and its position from the weir end (Ls), the near-bed velocity at the end of solid apron $\left(\mathrm{V}_{\mathrm{b}}\right)$ were measured (see Fig. (1)). 6) Tail-gate opening was changed and procedures from 2 to 5 were repeated for same discharge.

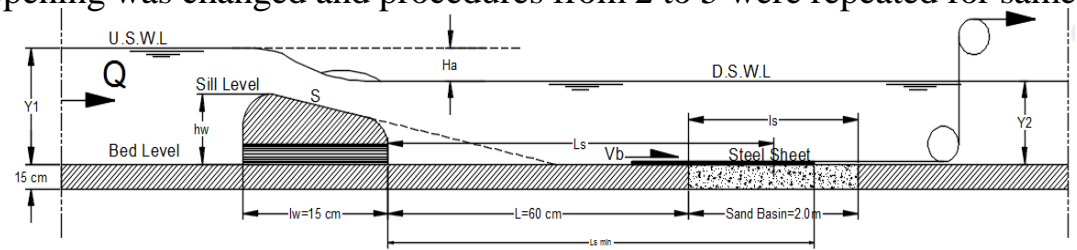

Fig. 2. Definition sketch showing the technique and governing parameters used in the second category.

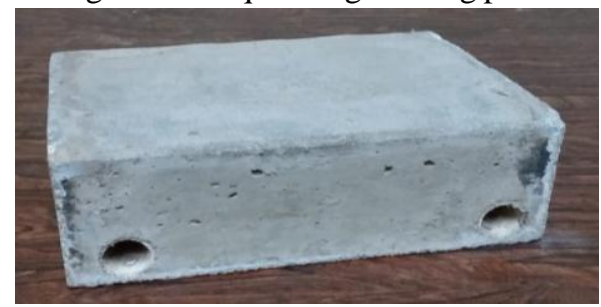

Photo 2. Upstream view of weir model showing bottom pipes.

7) The discharge was changed and steps from 2 to 6 were repeated three times for the same discharge to give the required range of Froude number. 8) Bottom pipes were opened (group 2), then procedures from 2 to 7 were repeated (see Fig. (2)). 9) New model with a new top surface slope was installed and procedures from 1 to 8 were repeated.

For the second category, same procedures of first one were repeated but the solid apron was extended using $1.5 \mathrm{~mm}$ thick and $300 \mathrm{~mm}$ wide steel plate till the scour is prevented, then the minimum solid bed length behind the weir to prevent scour was measured, (see Fig. 2).

\section{Theoretical approach}

The success of the method of dimensional analysis depends on the prescience in selecting the governing parameters. Scour length $\left(\mathrm{L}_{\mathrm{s}}\right)$ which equals to the distance from the weir end to the location of maximum depth of scour, maximum depth of scour hole $\left(\mathrm{d}_{\mathrm{s}}\right)$. The minimum

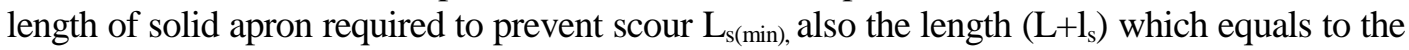
sum of an arbitrary length of floor (L) plus to total scour hole length $\left(1_{\mathrm{s}}\right)$, may be depended basically on upstream water depth $\left(\mathrm{Y}_{1}\right)$, downstream one $\left(\mathrm{Y}_{2}\right)$, total discharge passes to downstream through flume $\left(\mathrm{Q}_{\mathrm{t}}\right)$, near bed velocity of water measured at the end of solid apron $\left(\mathrm{V}_{\mathrm{b}}\right)$, the head difference between upstream and downstream water surfaces $\left(\mathrm{H}_{a}=\mathrm{Y}_{1}-\mathrm{Y}_{2}\right)$, weir 
height $(\mathrm{P})$, pipe diameter $(\mathrm{D})$, mean diameter of sand $\left(\mathrm{d}_{50}\right)$, critical flow depth $\left(\mathrm{Y}_{\mathrm{cr}}\right)$, channel width (B), specific weight of sand $\left(\gamma_{s}\right)$, gravitational acceleration $(\mathrm{g})$ and density, specific weight and absolute viscosity of water $\rho, \gamma$ and $\mu$ respectively. (see Figs. (1 and 2)).

The general functional relationship of these variables can be given by the following form:

$$
\phi=\left(\mathrm{L}_{\mathrm{s}}, \mathrm{d}_{\mathrm{s}} \mathrm{L}_{\mathrm{s}(\min ),}\left(\mathrm{L}+\mathrm{l}_{\mathrm{s}}\right), \mathrm{Y}_{1}, \mathrm{Y}_{2}, \mathrm{Q}_{\mathrm{t}}, \mathrm{V}_{\mathrm{b}}, \mathrm{H} a, \mathrm{P}, \mathrm{D}, \mathrm{d}_{50}, \mathrm{Y}_{\mathrm{cr}}, \mathrm{B}, \gamma_{s}, \rho, \gamma, \mu, \mathrm{g}\right)=0
$$

Applying the method of dimensional analysis, one can find;

$$
\phi_{1}=\left(\frac{\mathrm{L}_{\mathrm{s}}}{\mathrm{Y}_{2}}, \frac{\mathrm{d}_{\mathrm{s}}}{\mathrm{Y}_{2}}, \frac{\mathrm{L}_{\mathrm{s}(\min )}}{\mathrm{Y}_{2}}, \frac{(\mathrm{L}+\mathrm{ls})}{\mathrm{Y}_{2}}, \frac{\mathrm{Y}_{1}}{\mathrm{Y}_{2}}, \frac{\mathrm{H}_{\alpha}}{\mathrm{Y}_{2}}, \frac{\mathrm{P}}{\mathrm{Y}_{2}}, \frac{\mathrm{D}}{\mathrm{Y}_{2}}, \frac{\mathrm{Y}_{\mathrm{cr}}}{\mathrm{Y}_{2}}, \frac{\mathrm{B}}{\mathrm{Y}_{2}}, \frac{\rho \mathrm{Q}_{\mathrm{t}}}{\mathrm{Y}_{2} \mu}, \frac{\mathrm{Q}_{\mathrm{t}}^{2}}{\mathrm{gY}_{2}^{5}}, \frac{d_{50}}{\mathrm{Y}_{2}}, \frac{V_{b} Y_{2}^{2}}{Q}\right)
$$

The term $\left(Q_{t}^{2} / g y_{2}^{5}\right)$ is square Froude number $\left(F_{e}^{2}\right)$ while $\rho Q_{t} / \mu y_{2}$ is the Reynolds number $\left(\mathrm{R}_{\mathbf{e}}\right)$. The flow over sand bed exposed to erosion is ensured turbulent rough, consequently Reynolds' number effect on scour prediction is expected to be insignificant and it may be dropped from Eq. (3) Ali, 1978[18] and Chatterjee and Ghosh, 1980[19]. Powel, 1946 [20] found that the gravity starts to affect the flow resistance when Froude equals 2.49. Also, Ali [18] found the scour behind the sill located downstream sluice gate under submerged hydraulic jump was independent of Froude number. Various combinations of these variables can be used in a particular problem. All are theoretically equally valid but certain ones may produce better and significant relationships than others. So, considering the properties of dimensional analysis, Eq. (3) could be minimizing as follows:

$$
\frac{\mathrm{d}_{\mathrm{s}}}{\mathrm{Y}_{2}}, \frac{\mathrm{L}_{\mathrm{s}}}{\mathrm{Y}_{2}}, \frac{\left(\mathrm{L}+\mathrm{l}_{\mathrm{s}}\right)}{\mathrm{Y}_{2}} \text { and } \frac{\mathrm{L}_{\mathrm{s}(\mathrm{min})}}{\mathrm{Y}_{2}}=\varphi_{2}\left(\frac{\mathrm{H}_{\alpha}}{\mathrm{Y}_{2}}, \frac{B}{\mathrm{Y}_{\mathrm{cr}}}, \frac{\tau_{\mathrm{b}}}{\tau_{\mathrm{cr}}}\right)
$$

$\mathrm{Y}_{\mathrm{cr}}=$ critical flow depth $=\sqrt[3]{\left(Q_{t} / B\right)^{2} / g}, \tau_{\mathrm{b}}=$ bed shear stresses on sand surface at the beginning of sand basin due to flow motion which is given as [7]:

$$
\tau_{b}=\rho f V_{b}^{2} / 8
$$

where $f$ is the coefficient of friction and given from the following form [7]:

$$
1 / \sqrt{f}=2.0 \log \left(12.6 Y_{2} / d_{50}\right)
$$

and $\tau_{\mathrm{c}}=$ critical shear stresses in $\left(\mathrm{N} / \mathrm{m}^{2}\right)$ obtained from the following equation Leliavesky, 1965 [21]:

$$
\tau_{c}=\left(G_{s}-1\right) \gamma \varepsilon d_{50}
$$

$\mathrm{G}_{\mathrm{s}}$ is the specific gravity of sand, $\gamma_{s}$ in $\mathrm{N} / \mathrm{m}^{3}, \mathrm{~d}_{50}$ in meters and $\varepsilon$ is a parameter varies in range from 0.04 to 0.1 (Leliavesky, 1955) [23].

\section{Results and discussions}

Most of the previous studies analyzed the results of scour according the extreme dimensions of scour hole (i.e. maximum depth $\left(\mathrm{d}_{\mathrm{s}}\right)$ and its location behind the structures $\left(\mathrm{L}_{\mathrm{s}}\right)$ ) 
[5, 6, 9, 10 and 23]. In this study the analysis of scour parameters will be carried out in two cases; the first, when it is experimentally allowed the scour to form a hole and its parameters such as $\left(\mathrm{d}_{\mathrm{s}}, \mathrm{L}_{\mathrm{s}}\right.$ and $\left.\mathrm{l}_{\mathrm{s}}\right)$ are analyzed, while the second, when the scour is prevented and the minimum length $\left(\mathrm{ls}_{(\mathrm{min})}\right)$ of solid bed behind the weir to prevent scour is measured.

\section{First case:}

Figures (3 and 4) present the variation of dimensionless maximum scour depth $\left(\mathrm{ds} / \mathrm{Y}_{2}\right)$ with the dimensionless head difference $\left(\mathrm{H}_{\mathrm{a}} / \mathrm{Y}_{2}\right)$ at different values of $\left(\mathrm{B} / \mathrm{Y}_{\mathrm{cr}}\right)$ and top surface slope of 10:1 and 5:1 for solid and piped weirs respectively. The figures show the increase of scour depth with increasing the difference between the upstream and downstream water levels. Moreover, increasing the discharge which is represented by the form of critical depth $\left(\mathrm{B} / \mathrm{Y}_{\mathrm{cr}}\right)$ increases the scour depth. The scour behind the weir with top surface slope 10:1 is lower than that with 5:1except for high discharge of piped weirs. On other hand, it is clear that passing part of the discharge to downstream through the bottom pipes (piped weir) decreases the scour behind the weirs. This may due to the decrease of the head difference between upstream and downstream of the weir and may due to the increase of energy dissipation due to the interaction between the falling over weir flow and pipe flow. So, there is no scour problem with passing an additional part of the flow through the bottom pipes. The correlation of the experimental data is found in the power function as follows:

$$
\frac{d_{s}}{Y_{2}}=b\left(\frac{H_{a}}{Y_{2}}\right)^{c}
$$

where: $\mathrm{c}$ is a coefficients depending on weir top surface slope and b coefficients depending on the value of $\left(\mathrm{B} / \mathrm{Y}_{\mathrm{cr}}\right)$ and weir top surface slope as in Table (1).

Table 1.

Values of the coefficients in Eq. (8).

\begin{tabular}{|c|c|c|c|c|c|c|c|c|}
\hline & \multicolumn{4}{|c|}{ Values of (b) for: } & \multicolumn{4}{|c|}{ Values of (c) for: } \\
\cline { 2 - 9 } B/Ycr & Solid weir & \multicolumn{2}{|c|}{ Piped weir } & \multicolumn{2}{c|}{ Solid weir } & \multicolumn{2}{|c|}{ Piped weir } \\
\cline { 2 - 9 } & $10: 1$ & $5: 1$ & $10: 1$ & $5: 1$ & $10: 1$ & $5: 1$ & $10: 1$ & $5: 1$ \\
\hline 7.2 & 0.76 & 0.75 & 1.71 & 0.94 & & & & \\
\hline 7.87 & 0.67 & .67 & 1.19 & 0.9 & 0.48 & 0.88 & 0.99 & 0.81 \\
\hline 9.84 & 0.6 & .58 & 0.77 & 0.75 & & & & \\
\hline
\end{tabular}

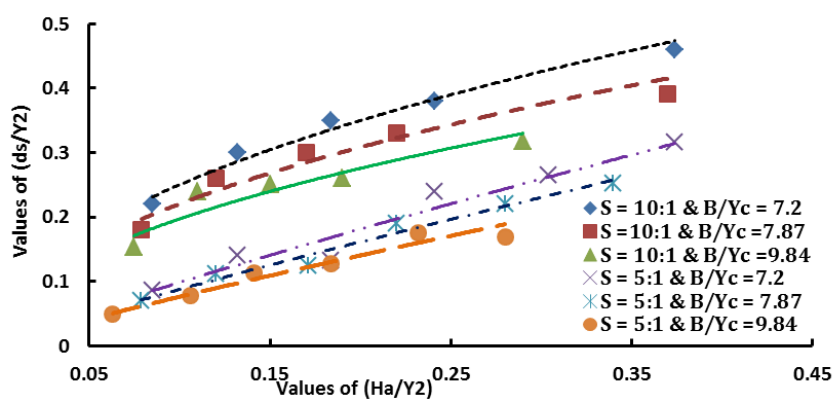

Fig. 3. Variation of $\left.\left(d_{s}\right) / Y_{2}\right)$ with $\left(H_{a} / Y_{2}\right)$ at different values of $\left(B / Y_{c r}\right)$ for solid weir with 10:1 and 5:1 top surface slopes. 


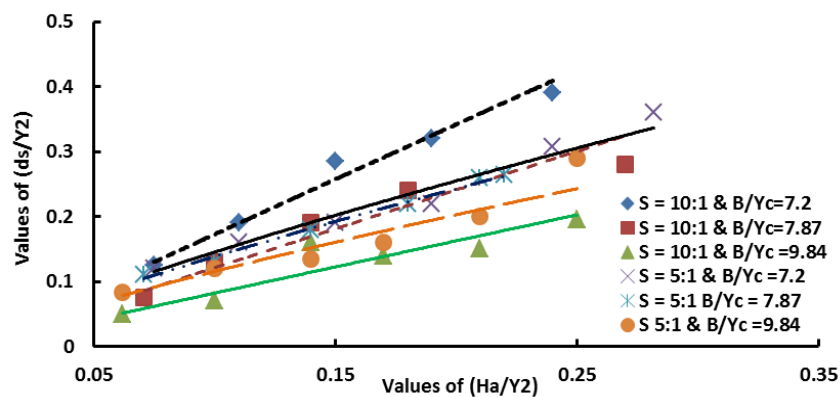

Fig. 4. Variation of $\left.(\mathrm{ds}) / \mathrm{Y}_{2}\right)$ with $\left(\mathrm{Ha} / \mathrm{Y}_{2}\right)$ at different values of $(\mathrm{B} / \mathrm{Ycr})$ for piped weir with 10:1 and 5:1 top surface slopes.

The experimental results on the location of maximum scour depth $\left(\mathrm{L}_{\mathrm{s}}\right)$ behind solid and piped weirs with top surface slopes 10:1 and 5:1 respectively are shown drawn in dimensionless form as in Fig. (5). The figure shows a little decrease in $\left(\mathrm{L}_{\mathrm{s}}\right)$ when using bottom pipes to pass a part of flow to downstream. This decrease is higher with weir has 5:1 top surface slope. This because the top surface slope 5:1 accelerates the flow to downstream and increases the impinging momentum at the channel bed. The dimensionless relationship may be correlated in the following form:

$$
\frac{L_{s}}{Y_{2}}=f\left(\frac{H_{a}}{Y_{2}}\right)^{k}
$$

Where: $\mathrm{f}$ and $\mathrm{k}$ are coefficients depending on the weir top surface slope as in Table (2).

Table .2.

Values of the coefficients in Eq. (9).

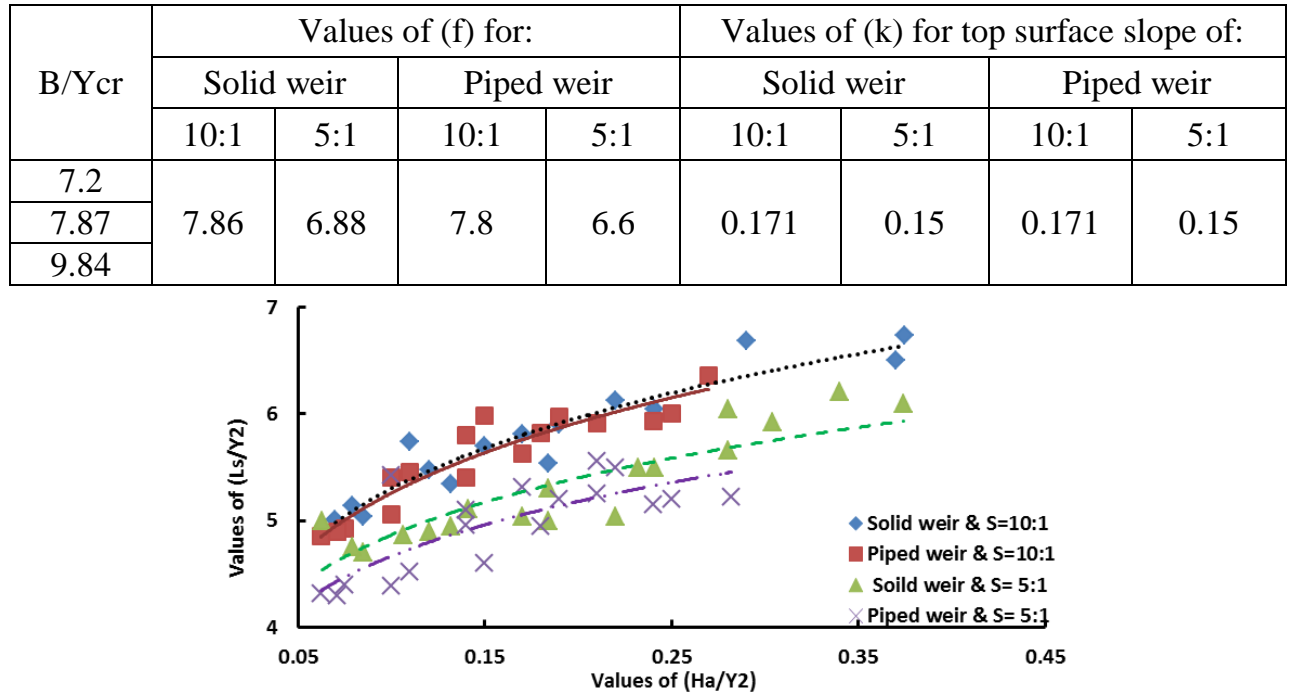

Fig. 5. Comparison between the variation of $\left(\mathrm{L}_{\mathrm{s}} / \mathrm{Y}_{2}\right)$ with $\left(\mathrm{H}_{\mathrm{a}} / \mathrm{Y}_{2}\right)$ for solid and piped weirs with 10:1 and 5:1 top surface slopes.

Bed shear stresses and critical ones are calculated according to Eqns. (5-7) for bed materials in sand basin behind solid and piped weir with 10:1 top surface slope. Figure (6) shows the drawings of dimensionless scour depth with that of shear stresses. It is seen for same scour dimensions, the values of shear stress ratio is smaller for piped weir than those 
of solid one and both are less than unity. So, the formation of scour may due to the turbulence associated with the top and bottom rollers behind the weir and may due to the escape of fine particles having small critical shear stress with existing values of bed ones. The higher values and the rapid increase of scour depth with bed shear stresses although of small values $\tau_{\mathrm{c}}$ when the pipes are working may due to the turbulence happened at the interaction between the streamlines of exit pipe flow with those coming from the over weir flow. Same results but with different values are obtained with the 5:1 top surface slope.

The dimensionless relationship may be correlated in the following form:

$$
\frac{L_{s}}{Y_{2}}=m\left(\frac{\tau_{b}}{\tau_{c}}\right)^{n}
$$

Where: $m$ and $n$ are coefficients depending on the weir top surface slope as in Table (3).

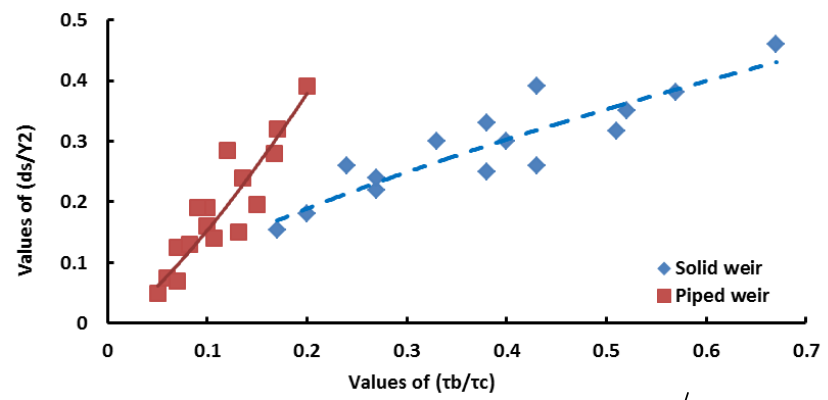

Fig. 6. Comparison between the variation of $\left(\mathrm{ds} / \mathrm{Y}_{2}\right)$ with $\left(\tau_{\mathrm{b}} / \tau_{\mathrm{c}}\right)$ for solid and piped weirs with 10:1 top surface slope.

Table 3.

Values of the coefficients in Eq. (10).

\begin{tabular}{|c|c|c|c|c|c|c|c|c|}
\hline \multirow{2}{*}{ B/Ycr } & \multicolumn{4}{|c|}{ Values of (m) for: } & \multicolumn{3}{c|}{ Values of (n) for top surface slope of: } \\
\cline { 2 - 9 } & \multicolumn{2}{|c|}{ Solid weir } & \multicolumn{2}{c|}{ Piped weir } & \multicolumn{2}{c|}{ Solid weir } & \multicolumn{2}{c|}{ Piped weir } \\
\cline { 2 - 9 } & $10: 1$ & $5: 1$ & $10: 1$ & $5: 1$ & $10: 1$ & $5: 1$ & $10: 1$ & $5: 1$ \\
\hline 7.2 & \multirow{2}{*}{0.565} & 0.697 & 3.106 & 0.345 & 0.68 & 0.465 & 1.307 & 0.551 \\
\hline 7.87 & & & & & & & & \\
\hline 9.84 & & & & & & & &
\end{tabular}

\section{Second case:}

In this case, the analysis are based on two phases; in the first one, it is considered that the length of solid apron required to prevent scour behind the weir model is combined from (the length of solid apron $(600 \mathrm{~mm})+$ the length of formed scour hole). The experiments show that, considering the combined length of first category as solid apron is not sufficient to prevent scour and additional scour hole is formed, so the minimum length of solid apron to prevent scour $\left(\mathrm{Ls}_{(\mathrm{min})}\right)$ was experimentally measured and will be analyzed in the second phase.

The dimensionless combined lengths $\left((\mathrm{L}+\mathrm{ls}) / \mathrm{Y}_{2}\right)$ are drawn against $\left(\mathrm{H}_{\mathrm{a}} / \mathrm{Y}_{2}\right)$ at different values of $\left(\mathrm{B} / \mathrm{Y}_{\mathrm{cr}}\right)$ with top surface slopes 10:1 and 5:1 for solid and piped weirs respectively as shown in Figs. $(7 \& 8)$. The drawings show same trend of increasing the combined length with the increase of both $\left(\mathrm{H}_{\mathrm{a}} / \mathrm{Y}_{2}\right)$ and $\left(\mathrm{B} / \mathrm{Y}_{\mathrm{cr}}\right)$. The correlation of the data found to follow the following exponential form: 


$$
\frac{(L+l s)}{Y_{2}}=p\left(\frac{H_{a}}{Y_{2}}\right)^{r}
$$

Where: $\mathrm{p}$ is a constant depending on the weir top surface slope and $\mathrm{r}$ coefficients depending on the values of $\left(B / Y_{\text {rr }}\right)$ and weir top surface slope as in Table (4).

Table 4.

Values of the coefficients in Eq. (11).

\begin{tabular}{|c|c|c|c|c|c|c|c|c|}
\hline \multirow{2}{*}{ B/Ycr } & \multicolumn{4}{|c|}{ Values of (r) for: } & \multicolumn{3}{c|}{ Values of (p) for top surface slope of: } \\
\cline { 2 - 9 } & \multicolumn{2}{|c|}{ Solid weir } & \multicolumn{2}{c|}{ Piped weir } & \multicolumn{2}{c|}{ Solid weir } & \multicolumn{2}{c|}{ Piped weir } \\
\cline { 2 - 9 } & $10: 1$ & $5: 1$ & $10: 1$ & $5: 1$ & $10: 1$ & $5: 1$ & $10: 1$ & $5: 1$ \\
\hline 7.2 & 12.393 & 12.729 & 15.33 & 9.258 & & & & \\
\hline 7.87 & 11.714 & 11.679 & 13.241 & 8.995 & 0.204 & 0.313 & 0.358 & 0.192 \\
\hline 9.84 & 11.25 & 11.038 & 12.405 & 8.734 & & & & \\
\hline
\end{tabular}

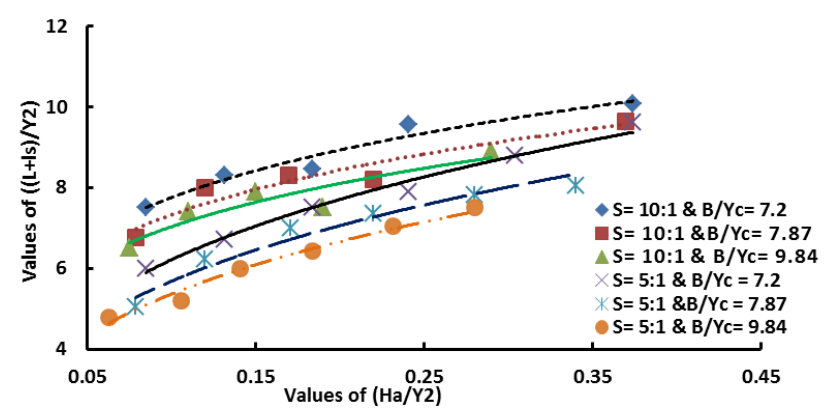

Fig.7. Variation of $\left((\mathrm{L}+\mathrm{ls}) / \mathrm{Y}_{2}\right)$ with $\left(\mathrm{H}_{a} / \mathrm{Y}_{2}\right)$ at different values of $\left(\mathrm{B} / \mathrm{Y}_{\mathrm{cr}}\right)$ for solid weir with 10:1 and 5:1 top surface slopes.

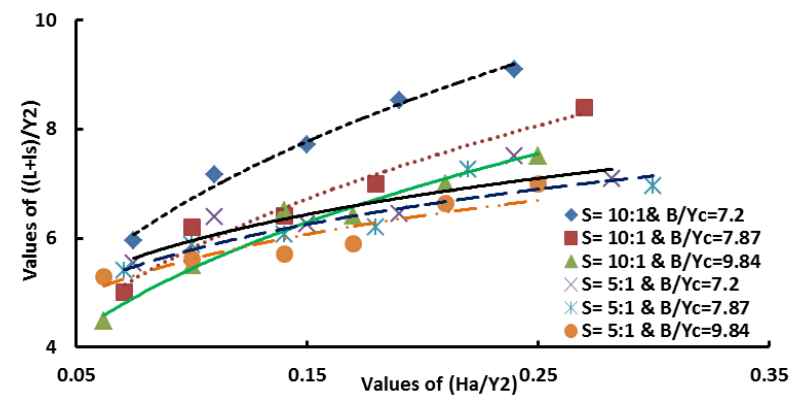

Fig. 8. Variation of $\left((\mathrm{L}+\mathrm{ls}) / \mathrm{Y}_{2}\right)$ with $\left(\mathrm{Ha} / \mathrm{Y}_{2}\right)$ at different values of $(\mathrm{B} / \mathrm{Ycr})$ for piped weir with 10:1 and 5:1 top surface slopes.

In the second phase of second case, the measured minimum-length of solid apron to prevent scour behind the studied weirs $\left(\operatorname{Ls}_{(\min )}\right)$ is drawn in dimensionless form against the values of $\left(\mathrm{H}_{\mathrm{a}} / \mathrm{Y}_{2}\right)$ at different values of $\left(\mathrm{B} / \mathrm{Y}_{\mathrm{cr}}\right)$ as in Figs. $(9 \& 10)$ for solid and pipes weirs respectively with 10:1 and 5:1 top surface slopes. From the figures, it is observed that top surface slope 10:1 needs longer solid apron than 5:1 for high discharges and low head differences. The correlation of the measured data found to follow the following exponential form:

$$
\frac{\left(L s_{(\min )}\right)}{Y_{2}}=u\left(\frac{H_{a}}{Y_{2}}\right)^{w}
$$


Where: $\mathrm{w}$ is a constant depending on weir top surface slope and $\mathrm{u}$ coefficients depending on the value of $\left(\mathrm{B} / \mathrm{Y}_{\mathrm{cr}}\right)$ and weir top surface slope as in Table (5).

Table 5.

Values of the coefficients in Eq. (12).

\begin{tabular}{|c|c|c|c|c|c|c|c|c|}
\hline \multirow{2}{*}{ B/Ycr } & \multicolumn{4}{|c|}{ Values of $(w)$ for: } & \multicolumn{2}{c|}{ Values of $(u)$ for top surface slope of: } \\
\cline { 2 - 8 } & \multicolumn{2}{|c|}{ Solid weir } & \multicolumn{2}{c|}{ Piped weir } & \multicolumn{2}{c|}{ Solid weir } & \multicolumn{2}{|c|}{ Piped weir } \\
\cline { 2 - 8 } & $10: 1$ & $5: 1$ & $10: 1$ & $5: 1$ & $10: 1$ & $5: 1$ & $10: 1$ & $5: 1$ \\
\hline 7.2 & 18.389 & 22.097 & 28.161 & 26.992 & & & & \multirow{2}{*}{0.329} \\
\hline 7.87 & 17.16 & 21.464 & 24.531 & 24.053 & 0.49 & 0.499 & 0.522 \\
\hline 9.84 & 16.294 & 18.606 & 22.103 & 2.342 & & & & \\
\hline
\end{tabular}

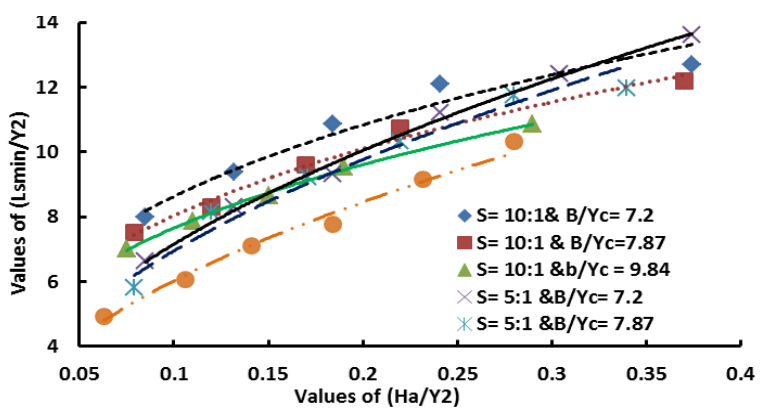

Fig. 9. Variation of $\left(\left(\mathrm{Ls}_{(\mathrm{min})}\right) / \mathrm{Y}_{2}\right)$ with $\left(\mathrm{Ha} / \mathrm{Y}_{2}\right)$ at different values of $(\mathrm{B} / \mathrm{Ycr})$ for solid weir with 10:1 and 5:1 top surface slopes.

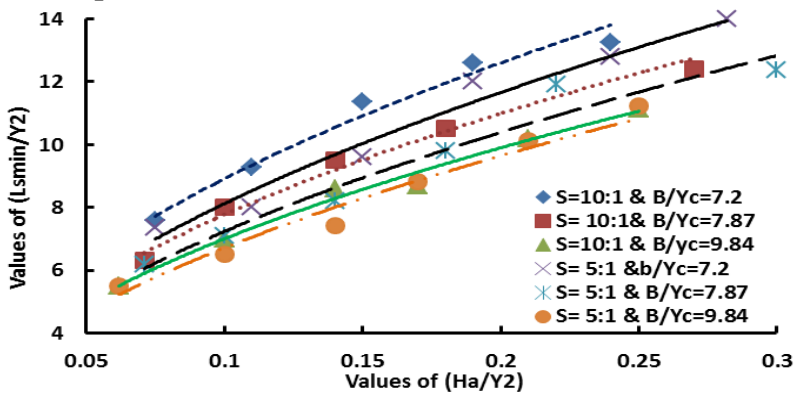

Fig. 10. Variation of $\left(\left(\mathrm{Ls}_{(\mathrm{min})}\right) / \mathrm{Y}_{2}\right)$ with $\left(\mathrm{Ha}_{\mathrm{a}} \mathrm{Y}_{2}\right)$ at different values of $(\mathrm{B} / \mathrm{Ycr})$ for piped weir with 10:1 and 5:1 top surface slopes.

\section{Verification of experimental results}

Based on velocity distribution approach, [Abozeid 1989][3] estimated the length of solid apron to prevent scour downstream the standing wave weir. Figure (11) presents the relations among the minimum length of solid apron to prevent scour $\left(\operatorname{Ls}_{(\min )}\right)$, length behind the weir to the location of maximum scour depth (Ls), the combination of arbitrary length of solid apron $(\mathrm{L}=600 \mathrm{~mm})+$ scour hole length (ls) and the estimated length of solid apron to prevent scour based on velocity distribution approach [3]. All are drawn in dimensionless form against $\left(\mathrm{Ha} / \mathrm{Y}_{2}\right)$ at $(\mathrm{B} / \mathrm{Ycr}=7.2)$ for weirs with top surface slope of 10:1. From the comparison between the results of the current study with that of [Abozeid 1989] [3] as shown in Fig.11, it is found that the estimated length of solid apron to prevent scour based on velocity distribution approach approximately equals to (the combination of arbitrary length of solid apron+ scour hole length $(\mathrm{L}+\mathrm{ls})$. Moreover the figure shows 
Gamal Abozeid et al., Experimental study on bed scour and its protection behind standing wave .........

$\left(\operatorname{Ls}_{(\min )}\right)$ is the longest one while the length behind the weir to the location of maximum scour depth (Ls) is the shortest.

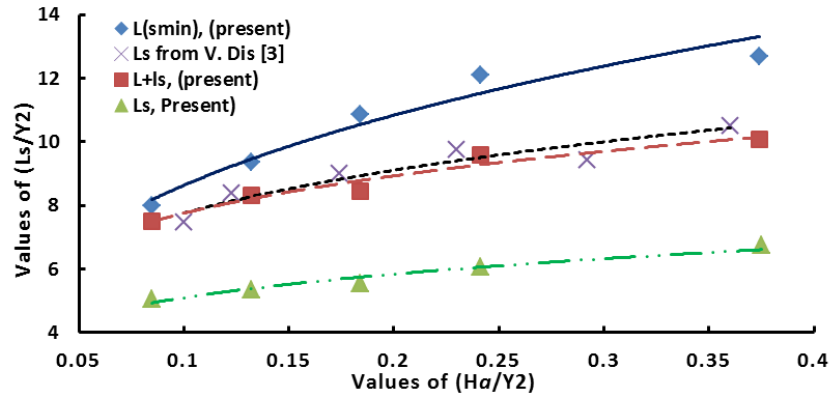

Fig. 11. Comparison between the variation of $\left(\mathrm{Lsmin} / \mathrm{Y}_{2}\right),\left((\mathrm{L}+\mathrm{ls}) / \mathrm{Y}_{2}\right)$ and results of velocity distribution $\left(\left(\mathrm{Ls} / \mathrm{Y}_{2}\right)[3]\right.$ with $(\mathrm{Ha} / \mathrm{Y} 2)$ at $(\mathrm{B} / \mathrm{Ycr}=7.2)$ for solid weir with 10:1 top surface slope.

\section{Conclusions}

As it is consistent from previous studies, that the use of standing wave weir with top surface slope 5:1 is the better for discharge measurement purposes [1] and using the weir with top surface slope 10:1 gives minimum scour downstream in comparison with another top surface slopes [3]. This study focused on these two cases considering the combination of over weir flow with that of bottom pipes. Moreover, the minimum solid bed length is studied as countermeasure of bed against scour.

The findings from this study may have practical applications when it is required to increase the passing flow rate from the upstream to downstream of the weir without affecting the safety of weirs and canal embankments and may be drawn as follows:

1) Using bottom pipes for passing flow with that falls over weir crest helps in reducing scour dimensions behind the weir, as well as reducing the required length of solid bed which considered bed protection.

2) The required minimum length of solid apron behind the weir to prevent scour is greater than the summation of an arbitrary solid length and the length of scour hole formed downstream of it.

3) The predicted length of scour behind the solid weir with top surface slope 10:1 is greater than that for 5:1 especially for high discharges and high head differences.

4) Empirical formulas in a power function were developed in dimensionless forms for estimating the protected scour dimensions of scour hole and the minimum length required to prevent scour the in the range of the experimental parameters mentioned in the experimental works and appeared on the figures.

5) From the comparative analysis with previous studies, it is found that the minimum length of solid bed behind the weir to prevent scour is greater than that one to protect the structure and the estimated one by using velocity distribution approach.

\section{REFERENCES}

[1] Ashour, M.A."Effect of surface slope on the ratio of submersion for the standing wave weir", M.Sc. Thesis, Faculty of Engineering, Assiut University, Egypt, 1974.

[2] Shehata, S. M.,"Characteristic of flow over weirs with bottom openings”, M.Sc. Thesis, Faculty of Engineering, Assiut University, Egypt, 2010. 
JES, Assiut University, Faculty of Engineering, Vol. 47, No. 4, July 2019, pp. 461-474

[3] Abozeid, G. A., "Scour below standing wave weir", M.Sc. Thesis, Faculty of Engineering, Assiut University, Egypt, 1989.

[4] El-Attar, S. T., "Study of scour below pipe culvert outlets" Eng. Res. J. Vol.5, PP 164-179, June, 1995.

[5] Abozeid, G. A.,"Estimation of the minimum floor length behind sluice gates against scour utilizing solid bed and erodible basin" J. of Eng. Scie. (JES), Faculty of Eng. Assiut Univ., Vol. 34, No. 4, July, 2006.

[6] Shenouda, A. GH.,"Scour Length Downstream Curved Weirs", M.Sc. Thesis, Aswan Faculty of Engineering, South Valley University, Egypt, 2008.

[7] Ali, N. A.," The proper location of floor sill with scour reach downstream of heading-up structure", J. of Eng. Scie. (JES), Faculty of Eng. Assiut Univ., Vol. 23, No. (2), July 1995.

[8] Negm, A .M.,"Effect of sill arrangement on maximum scour depth downstream of abruptly enlarged stilling basins", Eighth International Water Technology Conference, TWTC8, Alexandria, Egypt, 2004.

[9] Hossam, E. M." Estimation of scour length behind clear over fall weirs with bottom openings", M.Sc. Thesis, Aswan Faculty of Engineering, South Valley University, Egypt, 2012.

[10] Sobeih M. F., Helal, E. Y.2, Nassralla, T. H.3, and Abdelaziz, A. A., "Scour depth downstream weir with openings", Int. J. of Civil and Structural Eng.Vol. 3, No 1, 2012.

[11]Guan, D. Melville, B., and Friedrich, H., "Local scour at submerged weirs in sand-bed channels", J. of Hyd. Res. Vol. (54), No. (2), pp: 172-184, 2016.

[12] Shenouda, A. GH., “ Physical and Mathematical Modeling of Morphological Changes of Open Channels with Applications on River Nile", Ph.D. Thesis, Aswan Faculty of Engineering, South Valley University, Egypt, 20014.

[13] Googheri, Y. S., Saneie, M., and Ershadi, S., "Three-dimension numerical simulation of scour temporal changes due to flow in the downstream of combined weirs and gate model", Civil Eng. Jour., Vol. (3), No. 11, 2017. (http://civilejournal.org/index.php/cej/article/view/605/0)

[14] Lu Wang, Bruce, W. M. Dawei, G, and Colin, N. W., "local scour at downstream sloped submerged weirs", J. of Hyd. Eng. (ASCE)HY., Vol. (144) No. (8), 2018. (https://ascelibrary.org/doi/abs/ 10.1061/\%28ASCE\%29HY.1943-7900.0001492)

[15]Al-Husseini, T. R., Al-Madhhachi, A. T., and Naser, Z. A., "Laboratory experiments and numerical model of local scour around submerged sharp crested weirs", J. of King Saud Univ. - Eng. Sci., 2019.

[16] Bligh, W. G., “ The practical design of irrigation works,” Constable, $2^{\text {nd }}$ edn., London, 1912; Cited from [Abozeid 1989].

[17] Grade, R. J., Subramabya, K., and Nambudrpad, K. D., "Study of scour around spur dikes", J. Hyd. Div., ASCE, 87(6), 1961.

[18] Ali, N. A., "A contribution to sediment transportation with reference to hydraulic resistance", M. Sc. Thesis, Civil Eng. Dept. Assiut Univ., 1978.

[19] Chatterjee, S. S., and Ghosh, S. N., "Submerged horizontal jet over erodible bed ", J. of Hyd. Div., ASCE, 106(HY), Nov. 1980.

[20] Powel, R. W,”Flow in channel of definite roughness”, Trans., ASCE, (111), 1946.

[21] Leliavesky, S."Design of dams for percolation and erosion", Chapman \& Hall Ltd. London, Vol.III, 1965.

[22] Leliavesky, S., "An introduction to fluvial hydraulics", Constable \& Company LTD., London, 1955.

[23] Prins, J. E., "Phenomena related to turbulent flow in water control structures", Delft Hydraulic Lab. Publication No. 76, III, Sept., 1971. 
Gamal Abozeid et al., Experimental study on bed scour and its protection behind standing wave

\section{List of Symbols and Abbreviations}

The following symbols and abbreviations have been used in this paper:

\begin{tabular}{|c|c|c|}
\hline $\begin{array}{l}\text { Symbols and } \\
\text { Abbreviations }\end{array}$ & Description & Dimensions \\
\hline $\mathrm{B}$ & Canal bed width & $\mathrm{L}$ \\
\hline $\mathrm{D}$ & Bottom opening diameter & $\mathrm{L}$ \\
\hline $\mathrm{D}_{50}$ & Mean diameter of sand & $\mathrm{L}$ \\
\hline $\mathrm{d}_{\mathrm{s}}$ & Maximum scour hole depth & $\mathrm{L}$ \\
\hline $\mathrm{F}_{\mathrm{e}}$ & Froude Number & - \\
\hline$f$ & Friction factor & - \\
\hline $\mathrm{g}$ & Acceleration due to gravity & $\mathrm{LT}^{-2}$ \\
\hline $\mathrm{H}_{\mathrm{a}}$ & Head difference on the weir and pipes $\left(\mathrm{Y}_{1}-\mathrm{Y}_{2}\right)$ & $\mathrm{L}$ \\
\hline $\mathrm{L}$ & Arbitrary length of solid apron (chosen to be $60 \mathrm{~cm}$ ) & $\mathrm{L}$ \\
\hline $\mathrm{L}_{\mathrm{s}}$ & Location of maximum scour depth behind the weir & $\mathrm{L}$ \\
\hline $\mathrm{Ls}_{(\min )}$ & Minimum length of solid apron to prevent scour & $\mathrm{L}$ \\
\hline$l_{\mathrm{s}}$ & Total length of scour hole & $\mathrm{L}$ \\
\hline $\mathrm{P}$ & Weir height $(10: 1$ and $5: 1)$ & $\mathrm{L}$ \\
\hline $\mathrm{Q}_{\mathrm{t}}$ & Total flow rate passing to downstream & $\mathrm{L}^{3} \mathrm{~T}^{-1}$ \\
\hline $\mathrm{R}_{\mathrm{e}}$ & Reynolds' Number & - \\
\hline $\mathrm{S}$ & Weir top surface slope & - \\
\hline $\mathrm{V}_{\mathrm{b}}$ & Near bed velocity & $\mathrm{LT}^{-1}$ \\
\hline $\mathrm{Y}_{1}$ & Upstream water depth of the weir & $\mathrm{L}$ \\
\hline $\mathrm{Y}_{2}$ & Downstream water depth of the weir & $\mathrm{L}$ \\
\hline $\mathrm{Y}_{\mathrm{cr}}$ & Critical flow depth & $\mathrm{L}$ \\
\hline $\begin{array}{l}(b, c, f, k, m \\
n, p, r, u, w)\end{array}$ & Coefficients in the dimensionless equations & - \\
\hline$\varepsilon$ & parameter varies in range from 0.04 to 0.1 & - \\
\hline$\gamma$ & Specific weight of water & $\mathrm{ML}^{-2} \mathrm{~T}^{-2}$ \\
\hline$\gamma_{s}$ & Specific weight of sand & $\mathrm{ML}^{-2} \mathrm{~T}^{-2}$ \\
\hline$\rho$ & Density of water & $\mathrm{ML}^{-3}$ \\
\hline$\tau_{b}$ & Bed average shear stresses & $\mathrm{ML}^{-1} \mathrm{~T}^{-2}$ \\
\hline$\tau_{c}$ & Critical shear stresses of sand particles & $M L^{-1} T^{-2}$ \\
\hline$\mu$ & Absolute viscosity of water & $M L^{-1} \mathrm{~T}^{-1}$ \\
\hline Solid weir & Weir with over crest flow (closed bottom pipes) & - \\
\hline Piped weir & Weir with combined flow (opened bottom pipes) & - \\
\hline V. Dist. & Velocity Distribution approach & - \\
\hline
\end{tabular}




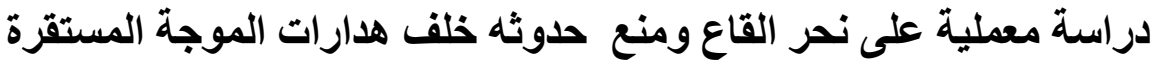

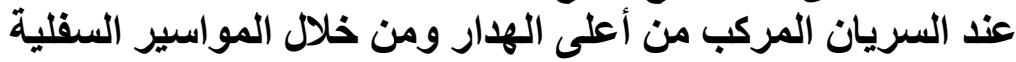

\section{الملخص العربي}

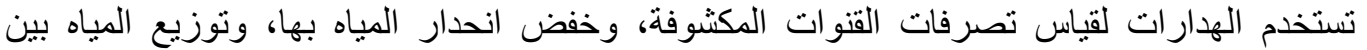

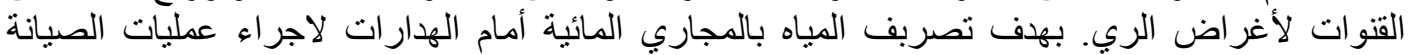

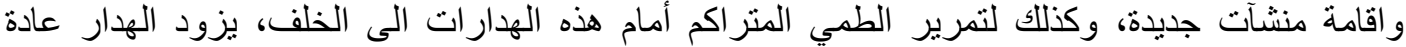

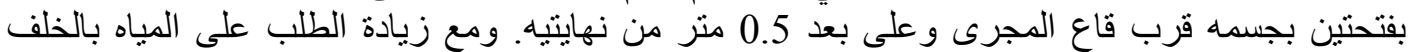

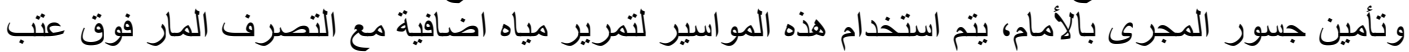

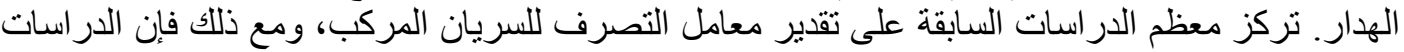

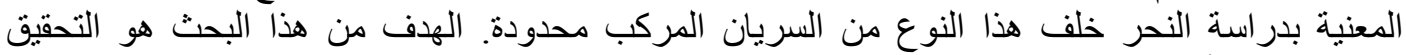

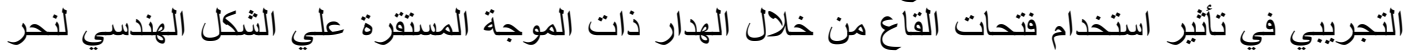

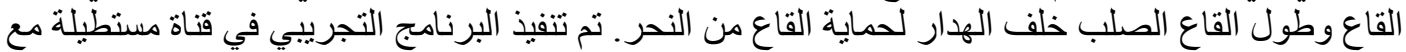

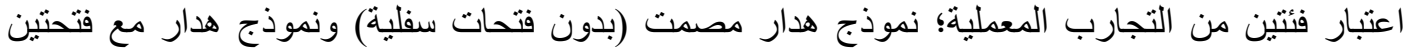

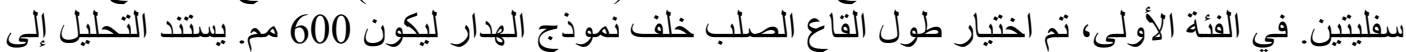

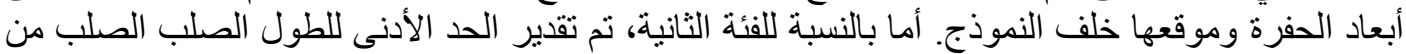

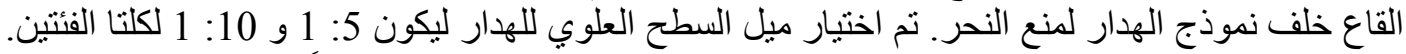

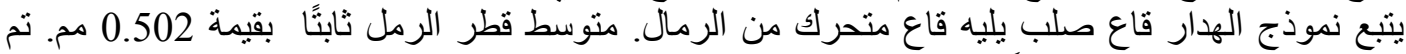

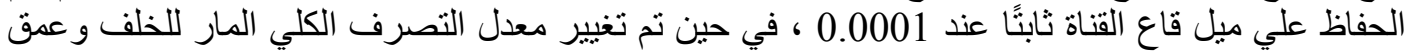

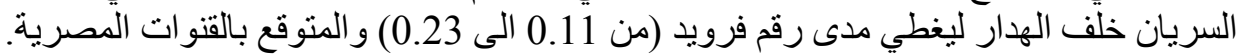

كثفت الدر اسة أن استخدام فتحات القاع لتمرير تصرف اضافي متزامنا مع السريان فوق عتب الهدار

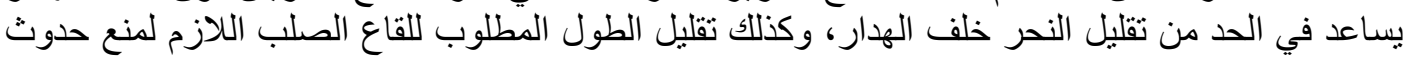

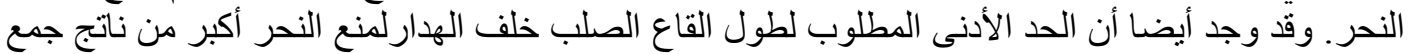

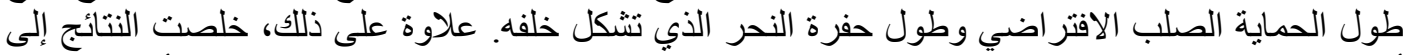

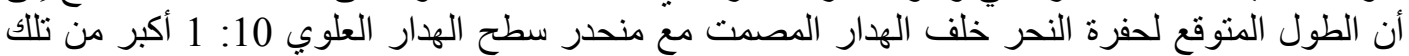

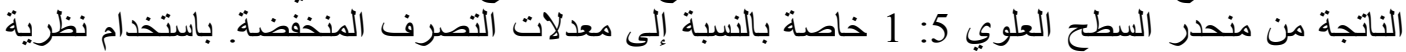

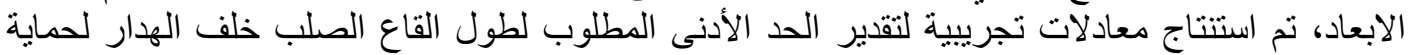

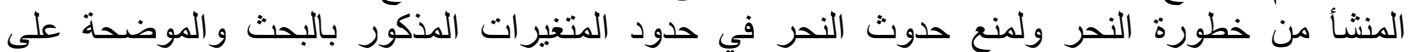

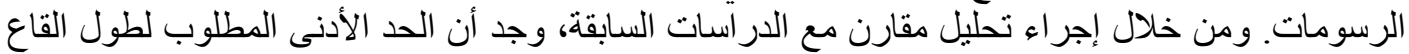

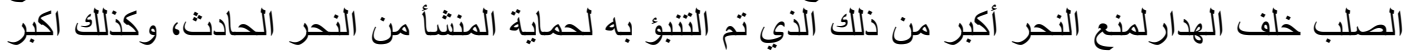

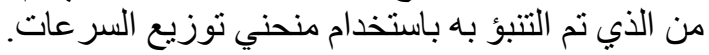

